
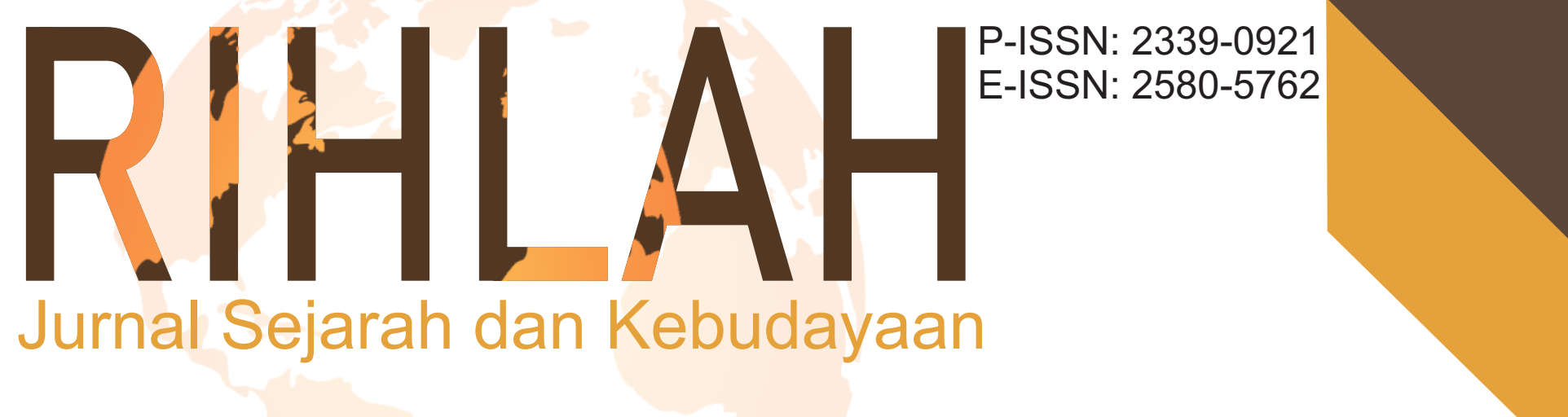

Article

Kebangkitan Kesultanan Ternate pada Era Reformasi 1998-2002 Rustam Hasyim, Oktosiyanti MT Abdullah, Siti Rahia H. Umar

Kondisi Politik Persia pada Era Dinasti Qajar 1796-1834 M Arafah Paramasto

Sultan Abdul Qahir dalam Pengembangan Islam di Bima Rahmat, Nurwahidah

Eksistensi Maccera Manurung dalam Perspektif Nilai Islam Sitti Fatimah Dwi Putri Islam dalam Tradisi Pernikahan Nuraeni

The Developments and Problems of Muslims in Australia Syamzan Syukur, Syamhi Muawwan, Syarifah Fauziah

Book Review

Historiografi Korupsi di Indonesia: Resensi Buku Korupsi dalam Miftakhuddin

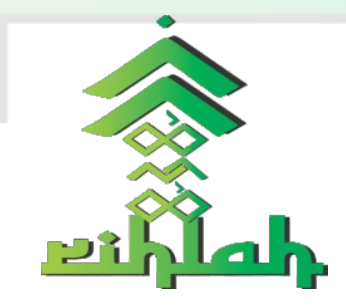




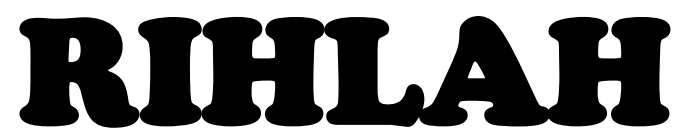

Jurnal Sejarah dan Kebudayaan

\begin{tabular}{|c|c|}
\hline Editor in Chief & Dr. Rahmat, M.Pd. \\
\hline Managing Editor & : Mastanning, S.Hum, M.Hum. \\
\hline Editorial Board & $\begin{array}{l}\text { Nur Ahsan Syukur, S.Ag, M.Si. } \\
\text { Muh. Iqbal S.Hum, M.Hum. } \\
\text { Chaerul Munzir, S.Hum, M.Hum. } \\
\text { : Lydia Megawati, S.Hum, M.Hum. } \\
\text { : Muhammad Husni, S.Hum, M.Hum. } \\
\text { Zaenal Abidin, S.S., M.H.I. } \\
\text { Chusnul Chatimah Asmad, S.IP, M.M. } \\
\text { : Muhammad Arif, S.Hum, M.Hum. }\end{array}$ \\
\hline Desain Grafis & : Nur Arifin, S.IP. \\
\hline Secretariat & Safaruddin, S.Hum. \\
\hline Reviewers & $\begin{array}{l}\text { Prof. Dr. H. Abd. Rahim Yunus, M.A. } \\
\text { Prof. Dr. H. Ahmad M. Sewang, M.Ag. } \\
\text { Dr. Hj Syamzan Syukur, M.Ag. } \\
\text { Dr. Nasruddin Ibrahim. } \\
\text { : Dr. Abd. Rahman Hamid. } \\
\text { St. Junaeda, M.Hum. } \\
\text { Dr. Syamhari, M.Pd. } \\
\text { Dr. A. Sukri Samsuri, M.Pd. }\end{array}$ \\
\hline
\end{tabular}

Alamat Redaksi dan Tata Usaha : Jurusan Sejarah dan Kebudayaan Islam Fakultas Adab dan Humaniora UIN Alauddin Makassar, Jln. Sultan Alauddin No. 36 Samata Gowa Tlp. 0411-841879 Fax. 0411-822140 (Kampus II) E.Mail. rihlah@uin-alauddin.ac.id

Jurnal Rihlah terbit dua kali dalam setahun, bulan Juni dan bulan Desember berisi kajian tentang Sejarah dan Kebudayaan, baik dari hasil penelitian maupun tulisan ilmiah lainnya.

Penyunting menerima tulisan yang belum pernah diterbitkan oleh media cetak lain. Naskah diketik spasi $1 \mathrm{~cm}$ pada kertas berukuran A4 dengan tulisan berkisar 12-23 halaman. Naskah yang masuk dievaluasi oleh Dewan Penyunting. Penyunting dapat melakukan perubahan pada tulisan yang dimuat untuk keseraganan format, tanpa mengubah maksud dan konten tulisan. 


\section{Daftar Isi}

Rustam, Oktosiyanti, Rahia

69-103

Kebangkitan Kesultanan Ternate pada Era Reformasi 1998-2002

Arafah Pramsto

104-125

Kondisi Politik Persia pada Era Dinasti Qajar 1796-1834

Rahmat, Nurwahidah

126-136

Sultan Abdul Qahir dalam Pengembangan Islam di Indonesia

Sitti Fatimah Dwi Putri

$.137-148$

Eksistensi Maccera Manurung dalam Perspektif Nili Islam

Nuraeni

$.149-158$

Islam dalam Tradisi Pernikahan

Syamzan, Syamhi, Syarifah 159-167

The Developments and Problems of Muslims in Australia

Miftakhuddin 168-172

Historiografi Korupsi di Indonesia: Resensi Buku dalam Silang

Sejarah Indonesia 


\title{
KONDISI POLITIK PERSIA PADA ERA DINASTI QAJAR 1796-1834 M
}

\author{
Arafah Pramasto \\ Pendamping Sosial Kota Palembang dan Penulis Buku Kesejarahan \\ arafahanakmadura@gmail.com
}

\begin{abstract}
The role of Qajar dynasty started as one of the tribal powers among the Qizilbash elite troops of the Safavid dynasty. Political conditions during the decline of Safavids led to the emergence of other warring dynasties to gain domination in Persia. This writing attempts to reveal political conditions of Qajar dynasty between 1796-1834 after the decline of Safavid Empire. The research method employed is library research within descriptive-analysis explanation. Qajar dynasty under the leadership of Agha Muhammad Khan was successful in defeating warring dynasties as the Russian invaders were also driven out. Agha Muhammad later became the Shah of Persia in 1796 year before he was assassinated during a military campaign against Russia. After his assassination, Fath Ali - nephew of Agha Muhammad became the new Shah in 1798. Qajar dynasty under the new reign effectively consolidated the political condition and governing aspect of Persia. Fath Ali is also believed to have committed violence against his competitors while also; he was able to coordinate between various cultural identities in Persia along with building country's governing structure as well as patronizing religious life. During later wars with Russia, Fath Ali was dependent on intervention of British and French due to lack of reforms in his military. It became an important event before his death in 1834.
\end{abstract}

Keyword: Qajar Dynasty; Political Condition; Persia.

\section{Abstrak}

Qajar pada awalnya merupakan salah satu suku dalam jajaran Qizilbash, pasukan elit Safawiyah. Kondisi politik pada masa keruntuhan Safawiyah dipenuhi berbagai dinasti yang saling berperang untuk memperebutkan dominasi atas tanah Persia. Tulisan ini bertujuan untuk mengungkap kondisi perpolitikan pada rentang waktu 1796-1834 di bawah Dinasti Qajar sebagai pewaris imperium Safawiyah di tanah Persia. Metode penelitian yang dipakai dalam kajian ini adalah riset kepustakaan dengan penkajian analisis deskriptif. Di bawah Agha Muhammad Khan yang dilahirkan pada 1742 M, dinasti Qajar berhasil meraih kekuasaan dengan menundukkan dinasti-dinasti yang bersaing serta menghalau ekpansi militer Rusia. Agha Muhammad Khan lalu dinobatkan sebagai Shah seluruh Persia pada tahun 1796, setahun sebelum kematiannya ketika melancarkan kampanye militer melawan Rusia. Pengganti Agha Muhammad adalah keponakannya yang bernama Fath Ali, ia dinobatkan sebagai Shah Persia pada tahun 1798 M. Baru pada masa pemerintahan Fath Ali Shah, Dinasti Qajar secara efektif mengonsolidasikan kondisi politik dan 
pemerintahan Persia. Walaupun Fath Ali turut melakukan kekerasan-kekerasan kepada para pesaing politiknya, ia mampu menaungi berbagai identitas etnis di Persia; membangun struktur pemerintahan negeri; dan menjadi patron kehidupan beragama. Namun dalam peperangan melawan Rusia, Fath Ali banyak bergantung pada intervensi Inggris dan Prancis serta kurang mendukung ide reformasi kemiliteran yang digagaskan putra mahkota Abbas Mirza : sebuah peristiwa penting sebelum kematian Fath Ali pada tahun 1834.

Kata Kunci : Dinasti Qajar; Kondisi Politik; Persia.

\section{Pendahuluan}

Di dalam bidang penulisan tentang sejarah Islam Iran di Indonesia, Dinasti Safawiyah cukup populer. Contohnya adalah buku Sejarah Peradaban Islam karangan Badri Yatim (2008) yang memasukkan Dinasti Safawi sebagai salah satu dari 'Tiga Kerajaan Besar' (1500-1800 M) bersandingan dengan Dinasti Utsmani dan Dinasti Mughal. ${ }^{1}$ Sayangnya, pengkajian itu tidak dilanjutkan hingga ke Dinasti Qajar. Begitupun dalam buku berjudul Dinasti-Dinasti Islam terjemahan dari The Islamic Dynasties (Edinburgh, 1980) karangan C.E. Bosworth, ulasan tentang Dinasti Qajar hanya sebanyak tiga halaman saja. ${ }^{2}$ Sumber literatur berbahasa Indonesia yang bisa dikatakan sebagai yang paling banyak dan cenderung komprehensif dalam mengkaji masalah Dinasti Qajar ialah buku Lintasan Sejarah Iran : Dari Dinasti Achaemenia ke Republik Islam Iran karangan Muhammad Hasyim Assagaf (2009), yang mana kemunculan hingga keruntuhan Dinasti ini dikaji dalam 46 halaman. Meski begitu, bagian buku itu memasukkan Dinasti Qajar bersamaan dengan Dinasti Pahlavi. ${ }^{3}$

Dapat dibilang bahwa selebihnya, kajian mengenai Dinasti Qajar cenderung menjadi materi tambahan dalam buku-buku bertema kesejarahan Iran - utamanya yang berkaitan dengan Revolusi Iran 1979 - dalam kaitannya sebagai pendahulu dari Dinasti Pahlavi. Salah satu contoh lainnya adalah buku Iran : Sejarah Persia $\mathbb{E}$ Lompatan Masa Depan Negeri Kaum Mullah (2010) karangan Ardison Muhammad. Buku ini menuliskan sejarah Qajar secara singkat dalam tiga halaman sebagai bagian dari rangkaian kronologis Dinasti-Dinasti sebelum masa Pahlavi, akan tetapi tidak sedikitpun menyebutkan nama-nama penguasa Dinasti tersebut, melainkan hanya peristiwa-peristiwa penting saja. ${ }^{4}$ Walaupun demikian, hal ini tidak menghalangi untuk kita memberikan apresiasi pada karya-karya tersebut, mengingat bahwa setiap buku mempunyai skup kajian spesifik tertentu, sehingga hal ini

${ }^{1}$ Lihat daftar isi buku karangan Badri Yatim, Sejarah Peradaban Islam Dirasah Islamiyah II, (Jakarta : PT. RajaGrafindo Persada, 2008), h. XII.

${ }^{2}$ Lihat C.E. Bosworth, Dinasti-Dinasti Islam, (Bandung : Mizan, 1993), h. 202-204.

${ }^{3}$ Lihat Muhammad Hasyim Assagaf, Lintasan Sejarah Iran : Dari Dinasti Achaemenia ke Republik Islam Iran, (Jakarta : The Cultural Section of Embassy of The Islamic Republic of Iran, 2009), h. 393-439.

${ }^{4}$ Lihat Ardison Muhammad, buku Iran : Sejarah Persia $\mathcal{E}$ Lompatan Masa Depan Negeri Kaum Mullah, (Surabaya : Liris, 2010), h. 81-83. 
memengaruhi para penulis untuk menetapkan apakah kajian mengenai Qajar perlu dilihat sebagai hal utama ataupun sebatas menjadi pelengkap.

Sebagaimana disebutkan di atas mengenai popularitas Dinasti Safawiyah dalam penulisan kesejarahan Iran di Indonesia, kemunculan Qajar sejatinya tidak dapat dilepaskan dari eksistensi Safawiyah. Berawal dari pembentukan pasukan elite Qizilbash di bawah Syaikh Haidar, pemimpin Tarekat Safawiyah dan ayah dari Shah Ismail I, Qajar merupakan salah satu suku dalam jajaran Qizilbash itu. Namun lebih dari itu, sebagaimana diungkapkan C.E. Bosworth, Persia di bawah pendiri Qajar lalu memasuki era modern, mendapatkan peranan strategis, dan ekonomi yang penting dalam urusan-urusan internasional. ${ }^{5}$ Melalui metode penelusuran kepustakaan, tulisan ini akan mengulas peristiwa-peristiwa penting dalam kehidupan politik Persia (sekarang Iran) yang berkaitan dengan pembentukan kekuasaan, persaingan-intrik dan peperangan sebagai dampak dinamika politik yang berasal dari dalam maupun luar negeri, pada lingkup waktu pemerintahan awal Dinasti Qajar antara 1796-1834.

\section{Agha Muhammad Shah}

Pada masa pemerintahan Shah Abbas I, penguasa Safawiyah kelima yang berkuasa pada 1588-1629, peran Qizilbash selaku pasukan elite yang sempat melakukan banyak intervensi seputar masalah politik sepeninggal Shah Ismail I telah diperkecil, namun tidak mudah untuk menghapus eksistensi Qizilbash sama sekali. Qizilbash didominasi oleh orang-orang Turkoman, bangsa yang mana Dinasti Safawi juga berasal. Ada tujuh suku yang mendominasi dalam Qizilbash seperti Ustadjlu, Rumlu, Shamlu (suku yang terkuat di masa Ismail I), Dulkadir / Dzulkadar, Afshar, Qajar, dan Takkalu. Peran awal Dinasti Qajar dimulai ketika bertindak sebagai vassal sekaligus kekuatan militer penyokong Dinasti Safawi di daerah Kaspia. ${ }^{6}$ Safawiyah yang kemudian melemah pasca wafatnya Shah Abbas I, kini mereka memasuki era kekacauan. Tahun 1722, orang-orang Afghan di bawah Mir Wais (mantan gubernur di bawah Safawi) berhasil merebut banyak wilayah Safawi. Kekacauan itu terhenti hingga seorang jenderal Safawi dari timur Iran yang bernama Nader Qoli merebut kembali wilayah dari tangan orang Afghan serta mengusir orang Utsmani keluar Hamedan.

Nader Qoli menyatakan diri sebagai penguasa dengan Dinasti barunya yang bernama Afshar, ia akhirnya terbunuh pada 1747 tanpa sempat menguasai wilayah seluas Dinasti Safawi. Sepeninggal Nader Qoli, Karim Khan Zand yang sebelumnya termasuk panglima pasukan Nader berhasil merebut kekuasaan dan mendirikan Dinasti Zand pada 1751. Namun Dinasti Zand juga gagal menyatukan kembali wilayah Persia sebagaimana era Safawi dahulu. Akhirnya, setelah kematian Karim Khan, Dinasti ini memasuki masa perang saudara. Dinasti Zand runtuh pada tahun 1794. Pengganti kuasa Zand adalah keluarga dari suku yang dahulunya mengabdi

${ }^{5}$ C.E. Bosworth, Dinasti-Dinasti Islam, h. 203.

${ }^{6}$ Patricia L. Baker, Hillary A. Smith, Iran, (Buckinghamshire : Bradt Travel Guide, 2014), h. 
sebagai Qizilbash. Semenjak awal penempatan kekuatan inti Safawi ditekankan kepada suku-suku dalam Qizilbash (yang mana Afshar dan Qajar adalah dua cabangnya), bisa dikatakan bahwa kuasa Dinasti tidak benar-benar berpindah tangan sama sekali, namun keduanya adalah keberlanjutan dari "intrik" Qizilbash seperti masa Safawi. ${ }^{7}$

Pendiri Dinasti Qajar adalah Muhammad Khan yang dilahirkan pada tahun 1742 sebagai putra dari Muhammad Hasan Khan, selaku kepala klan Qavanlu (Qoyunlu) cabang suku Qajar, pengaruh persaingan politik sudah sedemikian terasa dalam kehidupan Agha Muhammad. Kakek dari Agha Muhammad Khan pernah mengalami nasib naas karena menjadi tumbal politik sehingga dieksekusi mati oleh Shah Tahmasp II dari Dinasti Safawi. Kenyataan itu adalah penguatan sejarah yang menunjukkan walau bagaimanapun perkembangannya, meski setelah mengalami keruntuhan, presedensi sejarah oleh Safawiyah tetap saja mempengaruhi perpolitikan Persia. Sebagai dua klan terkuat di masa akhir Safawi, Zand dan Qajar terjebak dalam rivalitas politik.

Muhammad Khan tidak dapat mengelakkan takdirnya bahwa ia lahir di era yang mana Persia tengah diperbutkan oleh berbagai kekuatan suku yang saling berperang. Pergolakan tersebut nyatanya belum menghasilkan otoritas penguasa yang membawahi seluruh Persia sebagaimana Dinasti Safawi dahulu. Pada tahun 1759, ayahnya kehilangan wilayah barat Persia yang harus diserahkannya kepada Karim Khan Zand. Muhammad Khan kemudian ditangkap menjadi tawanan dalam salah satu istana Karim Khan. Nasib membawanya berpindah tangan menjadi tawanan Dinasti Afshar. Saat itu Muhammad Khan mendengar bahwa ayahnya terbunuh di tangan Karim Khan. Belum usai petaka yang mesti dialami Muhammad Khan. Di bawah perintah Adil Syah dari Dinasti Afshar, Muhammad Khan dikebiri. Suatu perbuatan kejam yang secara permanen merusak wataknya. ${ }^{8}$ Sejak saat itu Muhammad Khan memperoleh panggilan baru yakni "Agha", panggilan yang sering diberikan kepada seorang kasim istana. ${ }^{9}$

Agha Muhammad selanjutnya terus menjadi tawanan dalam istana Karim Khan di Syiraz hingga 16 tahun lamanya. Walaupun ia diperlakukan dengan baik sebagai sesama bangsawan suku - terkecuali dalam tragedi pengebiriannya - namun tetaplah bagi Agha Muhammad bahwa dirinya adalah tawanan. Karim Khan meninggal di tahun 1779 yang berbuntut pada pertikaian internal dalam Dinasti Zand, keadaan itu mempermudahnya untuk melarikan diri dari penawanan. Ia segera menuju wilayah suku Qajar yang terletak di timur laut Iran guna mengumpulkan dan mengomando pasukannya. Keberuntungan kemudian datang pada sang Agha yang telah memiliki tentara besar itu. Haji Ibrahim, wazir Dinasti

${ }^{7}$ D.L. Bradley, Dictionary of Iran : A Shorter Encyclopedia, (North Carolina : lulu.com Publisher, 2016), h. 574.

${ }^{8}$ Muhammad Hasyim Assagaf, Lintasan Sejarah Iran : Dari Dinasti Achaemenia ke Republik Islam Iran, 44.

${ }^{9}$ Alexander Mikaberidze (Ed.), Conflict and Conquest in the Islamic World : A Historical Encyclopedia,(California : ABC-CLIO,2011), h. 45. 
Zand yang mengagumkan memilih berpihak kepadanya. ${ }^{10}$ Pendukung yang menjadi kekuatan militer berjumlah sedemikian banyak, belum lagi orang-orang Haji Ibrahim yang ikut bergabung telah memperkuat militer Agha Muhammad. Ia terus terlibat dalam perang tiada henti untuk memenangkan dominasi, secara bertahap ia behasil mendirikan kekuasaannya di provinsi-provinsi utara Persia. Tahun 1781, Agha Muhammad berhasil mengusir ekspedisi laut Rusia yang ingin mendirikan basis di daerah dekat Ashraf. Dari 1782 hingga 1784 ia melakukan kampanye militer gemilang melawan Ali Murad Khan Zand, salah satu pengklaim takhta Zand. Sejak kemenangan itu Agha Muhammad menjadi penguasa tunggal di utara Persia. Ia lalu memindahkan ibukotanya ke Tehran, tempatnya dinobatkan (tanpa dimahkotai) menjadi penguasa pada tahun 1789 sebagai fondasi dasar Dinasti Qajar. ${ }^{11}$

Tehran sebelumnya memiliki kisah yang terkait dengan Karim Khan Zand, musuh dari ayah Agha Muhammad Khan. Akibat merasa terancam oleh kekuatan Qajar, dahulu Karim Khan mengirim pasukannya yang berbasis di ibukota Syiraz menuju Tehran pada tahun 1758, sebagai niatannya untuk menghindari musuh. Di waktu yang bersamaan ia berusaha mengelilingi Tehran dengan perbentengan serta memulai pembangunan pemukiman bagi keluarga kerajaan. Nampaknya setelah ia berhasil membunuh Muhammad Hasan Khan Qajar serta menawan Agha Muhammad dahulu, Karim Khan memilih untuk meninggalkan istana yang belum usai dibangun serta kembali ke Shiraz. ${ }^{12}$ Nampak bahwa pemilihan Tehran oleh Agha Muhammad juga dikarenakan nilai pskilogis-historis yang menggambarkan rasa takut dari Karim Khan Zand. Perlu diingat bahwa penobatan dirinya di Tehran ini memiliki arti yang lebih jauh ke depan. Tak bisa dipungkiri bahwa dengan mengalahkan banyak pihak, termasuk di antaranya adalah orang Rusia, menjadikan Agha Muhammad sebagai tokoh yang diperhitungkan untuk dapat menjadi penguasa seluruh wilayah Persia sebagaimana para penguasa dari Dinasti Safawiyah dahulu. Pemikiran seperti itu kelihatannya memang telah tersimpan dalam hatinya sejak lama atau mungkin baru saja tercetus setelah sejumlah kemenangan yang ia dapat.

Dalam tahun-tahun 1790-1794, Agha Muhammad meneruskan peperangannya melawan pengklaim takhta Zand lainnya. Meski prajuritnya menderita beberapa kali kekalahan melawan pangeran muda Zand, Lotf Ali Khan, akhirnya ia mampu berjaya di hadapan Dinasti Zand. Sisa keluarga Zand memilih bersembunyi dan mengungsi ke Kerman. Nasib menyedihkan kemudian menghampiri mereka, Agha Muhammad memerintahkan agar semua lelaki Zand dibunuh atau dibutakan dan lebih dari 20.000 wanita serta anak-anak dijadikan hamba sahaya. Ia perintahkan juga untuk menghancurkan dinding kota Shiraz, Islam Iran, 44.

${ }^{10}$ Muhammad Hasyim Assagaf, Lintasan Sejarah Iran : Dari Dinasti Achaemenia ke Republik

${ }^{11}$ Alexander Mikaberidze (Ed.), Conflict and Conquest in the Islamic World : A Historical Encyclopedia, h. 45.

${ }^{12}$ Pat Yale, dkk., Iran, (Victoria : Lonely Planet Publication, 2001), h. 155. 
menggali kembali makam Karim Khan dan membawanya kembali ke Tehran sebagai pembalasan dendamnya. ${ }^{13}$ Haji Ibrahim mempunyai andil besar untuk membantu Agha Muhammad mengalahkan dan menawan Lotf Ali Khan yang telah gagah berani berperang selama enam tahun. Penguasa Zand itu menerima penyiksaan yang sangat berat sampai akhirnya tewas terbunuh pada 1794 .

Mental Agha Muhammad Khan yang terganggu sejak mengalami nestapa di masa mudanya telah dapat menemukan pelampiasan terbaik melalui berbagai kemenangan yang diperolehnya. Keadaan ini tak lepas dari beragam kemungkinan. Pertama, Agha Muhammad Khan Qajar memang memiliki pengetahuan yang mumpuni dalam masalah kemiliteran sebagaimana ia adalah putra pemimpin suku. Kedua, Agha Muhammad telah mempelajari berbagai perkembangan persaingan politik dan militer Persia yang terjadi di antara banyak suku selama dalam penawanannya - tentu sebagai seorang kasim ia banyak memperoleh informasi dari para politisi di dalam istana Karim Khan. Ketiga, kerasnya hati untuk membalas segala kekejaman yang menimpa diri maupun ayahnya. Atau yang terakhir ialah perpaduan seluruh kemungkinan-kemungkinan itu. Jelasnya pada tahun 1795, Agha Muhammad Khan Qajar telah menguasai hampir seluruh wilayah Khorasan, sisa daerah kekuasaan Afshar, ia lalu menyiksa penguasa terakhir Afshar yakni Shah Rokh yang berujung pada kematian. ${ }^{14}$ Penyiksaan itu dilakukan karena Agha Muhammad memaksa Shah Rokh untuk menyebutkan tempat penyimpanan permata peninggalan Nader Qoli Afshar. Setelah mengaku, Shah Rokh dikirim ke Mazandaran bersama keluarganya, namun ia wafat (1796) karena luka-luka penyiksaan yang diderita.

Kini Agha Muhammad mengontrol seluruh Iran yang membuatnya dapat mengklaim wilayah kekuasaan Safawi di era sebelumnya. Ia lalu menatap jauh ke wilayah Kaukasus, di mana Kerajaan Kartli-Kakheti Georgia - dahulu menjadi negeri upeti (bawahan) Safawi - meminta bantuan Rusia dalam melawan Persia dan Utsmaniyah. ${ }^{15}$ Agha Muhammad memerintahkan pasukannya menyerang Heracle II dari Georgia yang telah menyatakan diri merdeka sejak mangkatnya Nader Qoli dan bahkan dengan berani mencaplok wilayah di tenggara sungai Aras. Penguasa Georgia itu mengaku berada dalam perlindungan Rusia. Agha bertindak cepat sehingga bisa mengalahkan Heracle II di medan perang, lalu merebut dan menjarahi Tblisi (Tiblis / Tiflis) sebelum Rusia sempat menolong Georgia. ${ }^{16}$ Jatuhnya Tblisi setelah pertempuran pahit itu berakibat pada penjarahan, jatuhnya

${ }^{13}$ Pat Yale, dkk., Iran, h. 155.

${ }^{14}$ D.L. Bradley, Dictionary of Iran : A Shorter Encyclopedia, h. 20.

${ }^{15}$ Alexander Mikaberidze (Ed.), Conflict and Conquest in the Islamic World : A Historical Encyclopedia, h. 45.

${ }^{16}$ Muhammad Hasyim Assagaf, Lintasan Sejarah Iran : Dari Dinasti Achaemenia ke Republik Islam Iran, h. 393-394. 
korban secara massif, dan sebanyak 15.000 orang Georgia dijadikan budak. ${ }^{17}$ Penguasa Qajar ini meninggalkan Tblisi untuk kemudian menaklukkan Erivan, Agha Muhammad lalu kembali ke Tehran dan dimahkotai selaku Shah Iran pada bulan Maret 1796, dalam prosesi itu ia bersandangkan pedang yang dimiliki Shah Ismail I Safawi. Ia berusaha menghidupkan kembali konsep Shah sebagai bayangan tuhan dan penguasa absolut. Agha menegaskan prinsip bahwa takhta harus diteruskan dari ayah ke anak, tujuannya adalah menghindari percekcokan suksesi takhta ataupun persaingan antar-suku seperti yang sudah-sudah. Kelak ia dan para penerusnya telah menjadi pusat kekuasaan Persia yang secara bertahap menaungi bermacam suku dan kekuatan politik lokal. ${ }^{18}$

"Shah" Agha Muhammad Khan Qajar sang penguasa bumi Persia itu harus menanggung konsekuensi dari watak kejamnya sendiri. Rusia akhirnya datang dan menyerang Iran barat laut serta berhasil merebut Derbent dan Baku. Karena kesigapan tentara Shah Agha Muhammad, Rusia berhasil dihalau saat ingin merebut Enzele. Pasukan Rusia kemudian memasuki Syamakhi yang terletak di Shirvan dan mengancam Azerbaijan. Orang-orang Georgia masih bersikeras dalam menolak status dominion Qajar atas wilayah mereka, pasukan Rusia juga telah siap untuk menaklukkan wilayah-wilayah pesisir Kaspia. Tetapi kemudian pasukan Rusia itu ditarik mundur karena wafatnya pemimpin negara mereka, Ratu Catherine. Meski begitu, pada tahun 1797 Agha Muhammad tetap berangkat lagi ke Georgia untuk menyerang Enzele, tetapi sebelum niatnya terlaksana ia mati terbunuh oleh dua orang pelayannya. Kedua pelayan itu telah dijatuhinya hukuman mati karena kesalahan yang sepele, dan sementara menunggu pelaksanaan hukuman mati itu, kedua terhukum masih disuruhnya bekerja seperti semula (tidak dikurung-Pen). ${ }^{19}$ Peristiwa naas itu terjadi pada hari ketiga setelah Agha Muhammad menduduki Shusha.

Keponakan favorit Agha Muhammad yang dipersiapkan sebagai penerus takhta, Baba Khan, naik ke atas singgasana dengan nama gelarnya "Fath Ali Shah". ${ }^{20}$ Para pengamat Barat banyak yang menganggap Agha Muhammad adalah pemimpin yang tidak hebat dan tidak kapabel pula, meski ia adalah pendiri Dinasti dengan berbagai kemenangan. Mungkin hal itu dikarenakan kekejaman yang kerap ia lancarkan pada musuh-musuhnya. Namun, demikianlah kisah sang pendiri Dinasti Qajar. Agha Muhammad memang keras, tapi ia juga manusia yang hidup dengan luka batin yang mendalam di era kekacauan Persia. Jelasnya, hasil jerih payah Shah Agha Muhammad Khan telah melahirkan sebuah otoritas politik Persia yang diperhitungkan : Dinasti Qajar.

${ }^{17}$ Jeremy Black, War in the Eighteenth-Century World, (Hampshire : MacMillan Palgrave, 2012), h. 141.

${ }^{18}$ John Middleton, World Monarchies and Dynasties, (New York : Routledge, 2015), h. 761.

${ }^{19}$ Muhammad Hasyim Assagaf, Lintasan Sejarah Iran : Dari Dinasti Achaemenia ke Republik Islam Iran, h. 393-394.

${ }^{20}$ William Bayne Fisher, P. Avery, The Cambridge History of Iran, Volume 7, (New York : Cambridge University Press, 1968), h. 329. 


\section{Penobatan Fath Ali Shah}

Fath Ali Khan yang dikenal juga dengan nama Baba Khan adalah putra dari saudara Agha Muhammad Khan yang bernama Hossein Qoli Khan Qajar. Ia dilahirkan pada tanggal 5 September 1772 di Damghan. Ayah dari Fath Ali, Hossein Qoli, mati terbunuh oleh orang-orang Turkoman atas hasutan dari klan Yukharibash, cabang Develu suku Qajar. Yukharibash sudah sejak lama menjadi musuh (rival) dari Qajar-Qavanlu dan terbiasa dengan istilah "penebusan darah" (balas dendam) antar mereka, namun menurut Daniel T. Potts dengan mengutip sejarawan Qajar, Hasan E-Fasa'i, setelah Agha Muhammad Khan menunjukkan penyesalan dan menyayangkan kekerasan antara keduanya (Qavanlu dan Yukharibash), para Khan dari cabang Develu "merubah sikapnya dan menerimanya (Agha Muhammad Khan) dengan senang hati." ${ }^{21}$ Saat pamannya terbunuh, Fath Ali sedang memimpin wilayah Fars sebagai gubernur. Masa lalu Agha Muhammad Khan yang dikebiri, telah membuatnya mempersiapkan sejak jauh-jauh hari penobatannya sebagai Shah, ia ingin agar keponakannya yakni Fath Ali Khan sebagai pewaris takhta. ${ }^{22}$ Dengan demikian, sesungguhnya Agha Muhammad telah mempersiapkan pra kondisi yang baik untuk masa depan Fath Ali yakni persatuan antar-klan Qajar ataupun tentu bagi kelancaran menuju takhta.

Fath Ali baru dimahkotai sebagai Shah ialah pada tanggal 19 Maret 1798, pada tahun berikutnya ia menetapkan bahwa anaknya yakni Pangeran Abbas Mirza selaku putra mahkota. Abbas dilahirkan pada 26 Agustus 1789 di sebuah desa bernama Nava, Mazandaran, Ibundanya bernama Asiyeh Khanoum. Anak tertua Fath Ali Shah bernama Muhammad Ali Mirza Dowlatshah (1. 1 Januari 1789), dilahirkan di tempat yang sama dengan Abbas Mirza namun dari ibu seorang gadis budak asal Georgia yang berubah nama menjadi Ziba Chehr Khanoum Gorji. Dowlatshah tak pernah bisa mewarisi takhta karena garis ibunya yang bukan dari Dinasti - atau minimalnya - orang Qajar. Abbas Mirza kemudian diberi kewenangan untuk memerintah Azerbaijan, provinsi yang rentan oleh ancaman Ottoman maupun Rusia. Abbas bukanlah putra tertuanya, kemungkinan pula juga bukan yang paling cakap, tapi yang terpenting ibu dari Abbas ialah anak wanita dari Develu Qajar : pemilihan Abbas sebagai putra mahkota akan memperkuat persatuan sesama suku Qajar. Fath Ali Shah ialah penguasa yang juga dikenal secara khas dengan janggut hitam panjangnya, di samping "ratusan" selir beserta anakanaknya. Para penerus Fath Ali kelak mewarisi bermacam masalah akibat besarnya anggota aristokrasi yang telah ia ciptakan. ${ }^{23}$

Agha Muhammad memang tentu sudah menetapkan takhta bagi Fath Ali agar kemudian keponakannya itu tidak mendapati adanya tantangan, meski begitu sempat muncul ancaman yang agak serius datang dari pemimpin etnis Kurdi

${ }^{21}$ Daniel T. Potts, Nomadism In Iran : From Antiquity to the Modern Era, (New York : Oxford University Press 2014), h. 268.

${ }^{22}$ John H. Lorentz, The A to Z of Iran, (Maryland: Scarecrow, 2010), h. 8.

${ }^{23}$ John H. Lorentz, The A to Z of Iran, h. 101. 
bernama Sadeq Khan Shaqaqi, gelagatnya mulai terasa sejak peristiwa pembunuhan Agha Muhammad. Sadeq bahkan telah membuat mahkota bertakhtakan berlian dan menghimpun pasukan besar demi merebut Tehran. Balatentara Fath Ali Shah berhasil menundukkan Sadeq dengan telak pada Agustus 1798. Saudara Fath Ali lainnya yang bernama Husayn Qoli Khan juga meminta agar diberi kekuasaan, permintaan itu diganjar hukuman mati oleh Fath Ali pada tahun $1803 .{ }^{24}$

Di masa awal kekuasaannya, Fath Ali telah menunjukkan keseriusan dalam mempertahankan takhta kekuasaan Qajar. Ada satu peristiwa lain yang begitu menguatkan kesan tersebut. Ialah Haji Ibrahim, seorang tokoh yang berperan dalam pendirian Dinasti Qajar dengan membantu perjuangan Agha Muhammad yang harus merasakan konsekuensinya. Haji Ibrahim yang bernama lengkap Haji Ibrahim Kalantar Shirazi, seorang yang dahulu pernah menjabat walikota Shiraz di masa pemerintahan Karim Khan Zand namun berbalik melawan Lotf Ali, beserta banyak tentaranya ia bergabung dengan Agha Muhammad. Alhasil, ketika Agha Muhammad berkuasa / berhasil mendirikan Dinasti Qajar, Haji Ibrahim dipercaya untuk menduduki jabatan Perdana Menteri dalam pemerintahan Qajar. Haji Ibrahim berperan besar dalam permasalahan negara seperti menyatukan selatan Persia (Iran) dengan wilayah Qajar di utara, mengorganisir administrasi Qajar, menjaga keutuhan militer setelah tewasnya Agha Muhammad, dan bahkan memastikan amanat agar Fath Ali selaku penerus takhta bisa terlaksana. Tetapi dengan meniupkan tuduhan konspirasi, Fath Ali mencopot Ibrahim Kalantar sebagai Perdana Menteri pada bulan April 1801. Haji Ibrahim ditangkap, dimutilasi, dan kemudian dibunuh bersama keluarganya. Mungkin terdapat alasanalasan lain dalam pencopotan Haji Ibrahim dari jabatannya, tapi tetap saja eksekusi kejam tersebut merupakan balasan pahit bagi peranan penting Haji Ibrahim Kalantar pada Qajar. ${ }^{25}$

Mengenai hukuman mati yang ditimpakan Fath Ali kepada Haji Ibrahim itu diyakini memiliki sebab yang paling diyakini oleh sejumlah sejarawan. Seperti Saeed Shirazi dalam bukunya A Concise History of Iran : From the Early Period to the Present Time mengungkap Haji Ibrahim memang mengabdi pada Shah namun ia juga dipengaruhi oleh intervensi pihak asing (Inggris-Pen) dalam urusan istana Persia, sehingga hal ini membuat Fath Ali menjadi khawatir atas bertambahnya pengaruh politik dari perdana menterinya itu. ${ }^{26}$ Hampir serupa dengan pendapat Shirazi, Zackery M. Heern berpendapat dalam karyanya yang berjudul The Emergence of Modern Shiism : Islamic Reform in Iraq and Iran bahwa kelihatannya pengaruh Haji Ibrahim telah sedemikian kuat (terhadap kekuasaan - Pen) dalam pandangan Fath

${ }^{24}$ Elton L. Daniel, The History of Iran (2nd Edition), (California : Greenwood, 2012), h. 101.

${ }^{25}$ Elton L. Daniel, The History of Iran (2nd Edition), h. 101.

${ }^{26}$ Saeed Shirazi, A Concise History of Iran : From the Early Period to the Present Time, (Los Angeles USA : Ketab Corporation, 2018), h. 243. 
Ali Shah. ${ }^{27}$ Terlihat dari pendapat-pendapat tersebut, masalah kuatnya pengaruh dari Haji Ibrahim atas kepemimpinan Fath Ali merupakan sesuatu yang dominan, sehingga tuduhan "konspirasi" dengan Inggris yang dilakukan Haji Ibrahim sepertinya hanya isu yang diangkat oleh Fath Ali, terlebih kelak di kemudian hari justru Fath Ali sendiri yang malah berhubungan cukup dekat dengan Inggris.

Selama pemerintahannya, kekuasaan Shah dikonsolidasikan sedemikian rupa serta administrasi berkembang semakin kompleks dan terpusat. Beberapa kementerian baru juga dibentuk pada masa ini. Selain keberadaan Monshi AlMamalek atau sekretaris pribadi Shah dan Lashkar Nevis yakni Menteri Peperangan, dibentuk pula Saheb Divan atau bagian penggajian para pegawai pemerintah. Menteri Kepala atau "Kanselir" berada di bawah jabatan Sadr A'zam, tugasnya ialah mengatur administrasi kenegaraan sehari-hari. Semua pejabat tinggi (menteri) di masa itu merupakan "pembantu" pribadi shah yang menjabat sesuai kehendak penguasa. Sejak masa Agha Muhammad juga telah ada jabatan-jabatan khusus lainnya seperti yang berkaitan dengan bidang keilmuan seperti Monajjembashi yakni "Kepala Astrolog" dan Hakimbashi atau "Kepala Tabib." Untuk posisi Kepala Tabib perlu ditekankan bahwa itu tentu bukan sesuatu hal yang baru karena semua penguasa dan Dinasti-Dinasti Persia sebelumnya juga memiliki tabib masingmasing. ${ }^{28}$

Secara umum bisa dikatakan Fath Ali dengan berbagai kebijakankebijakannya lebih lunak dibandingkan dengan Agha Muhammad. Meski (di sisi lain) eksekusi terhadap Haji Ibrahim Kalantar pada masa permulaan pemerintahannya bisa diibaratkan "merebus si menteri malang dalam minyak" yang menunjukkan kebrutalannya dalam menyikapi orang yang tak dikehendakinya. ${ }^{29}$ Pendapat tersebut bisa dibuktikan kebenarannya secara historis karena ia tidak dalam posisi yang kritis sebagaimana halnya Agha Muhammad selaku pendiri dinasti, yang mesti memenangkan persaingan dominasi melawan Dinasti-Dinasti lain demi mempersatukan Persia dan menjamin bertahannya dominasi Qajar dari gangguan dalam maupun luar negeri.

Bagaimanapun dalam sistem monarkhi absolut ada beberapa jabatan yang bisa diwariskan dan didominasi oleh keluarga-keluarga tertentu, walau terkadang juga gelar-gelar kehormatan tidak bisa diwariskan terkecuali dalam kasus-kasus tertentu. Fath Ali juga dikenal lebih konsisten dibandingkan Shah Agha Muhammad dalam merekrut para sekretaris dan pejabat-pejabat kota dari Mazandaran dan Irak 'Ajam maupun sisa-sisa keluarga birokrat Zand dari Fars. Para pegawai maupun pejabat lumrahnya memiliki hubungan yang erat dengan para Ulama, pedagang-pedagang Bazaar (pedagang pasar / 'Bazaaris'), dan para orang-

${ }^{27}$ Zackery M. Heern, The Emergence of Modern Shiism : Islamic Reform in Iraq and Iran, (London : Oneworld, 2015), h. 53.

${ }^{28}$ Hormoz Ebrahimnejad, Medicine, Public Health, and the Qajar State, (Leiden : Brill, 2004), h. 88-89.

${ }^{29}$ Elton L. Daniel, The History of Iran (2nd Edition), h. 101. 
orang penting selaku penghubung dengan kalangan-kalangan itu. Jajaran pemerintahan Fath Ali pun memuat komponen orang-orang Georgia yang memiliki akar sebagai budak. Beberapa di antaranya ada yang bekerja sebagai kasim atau pembantu istana, maupun masuk ke jajaran militer. ${ }^{30}$

Fath Ali turut menunjukkan pentingnya komposisi orang-orang dari Mazandaran dan Irak 'Ajam dalam jajaran kemiliteran setelah Suku Qajar. Fath Ali memiliki pengawal pribadi 3000-4000 orang dengan cadangan kekuatan sebanyak 12.000 orang, kebanyakan di dalam komposisi prajurit itu ialah dari suku Qajar dan orang-orang Mazandaran. Kontingen-kontingen dalam barisan itu juga diisi oleh orang-orang dari berbagai provinsi seperti Azerbaijan dan Iraq 'Ajam. Dalam masalah pengupahan, seringkali terjadi penunggakan karena kenyataannya tidak ada pengawasan yang tepat : akibatnya terjadilah "kampanye militer musiman" (untuk mencari rampasan perang-Pen) karena prajurit tidak dapat bertahan sepanjang tahun dengan keadaan itu. ${ }^{31}$ Sistem kemiliteran kelihatannya belum terorganisir sempurna sebagaimana dalam bentuk militer modern, termasuk di dalamnya ialah masalah penggajian. Sepertinya Saheb Divan tidak mengurus masalah kemiliteran yang berada di bawah Lashkar Nevis.

Selain itu dalam bidang keagamaan, Mullabashi merupakan jabatan tertinggi urusan keagamaan negara di era akhir Safawi hingga masa awal Qajar. Mullah Muhammad Husayn dari Mazandaran adalah Mullabashi pertama Qajar yang digantikan kemudian oleh Mullah Ali Asghar (dilanjutkan kemudian oleh putranya yang bernama Mirza Ali) hingga masa Fath Ali. Jabatan Mullabashi terlihat sebagai jabatan warisan, kemungkinannya ialah bahwa posisi itu merupakan otoritas tertinggi bagi urusan keagamaan negara hingga mangkatnya Fath Ali Shah kelak. ${ }^{32}$ Fath Ali, menurut pendapat Heern, dengan "tanpa lelah" selalu berusaha untuk memperkuat legitimasi Qajar dengan mencari dukungan melalui penetapan para ulama Syiah. ${ }^{33}$ Maka apabila dilihat pendapat Heern tersebut, kaum agamawan seperti memiliki posisi khusus dalam "kepentingan" Fath Ali sebagai seorang Shah. Namun bukan berarti bahwa jabatan keagamaan secara mutlak dibentuk karena asas kepentingan itu saja, mengingat Persia Qajar adalah sebuah monarkhi Muslim maka keberadaan jabatan ini juga didasari oleh aspek kebutuhan untuk memanajemen urusan agama negara dan rakyat.

Terdapat sebuah kejadian yang menunjukan perhatian khusus Fath Ali pada urusan agama, contohnya dituliskan Dr. Ali Peiravi sebagai penerjemah bahasa Arab-Inggris dari Kitab Uyun Akhbar Al-Ridha (The Source of Traditions on Imam Reza (s)) karya Syaikh Shaduq pernah menukilkan kisah dalam pengantarnya.

\footnotetext{
${ }^{30}$ Abbas Amanat, Pivot of the Universe : Nasir al-Din Shah Qajar and the Iranian Monarchy 1851-1896, (London : I.B. Tauris, 1997), h. 4.

${ }^{31}$ (Ann. K.S. Lambton, Bernard Lewis (Ed.), The Cambridge History of Islam , (London : Cambridge University Press, 1970), h. 436.

${ }^{32}$ Ann. K.S. Lambton, Bernard Lewis (Ed.), The Cambridge History of Islam , (London : Cambridge University Press, 1970), h. 436.

${ }^{33}$ Zackery M. Heern, The Emergence of Modern Shiism : Islamic Reform in Iraq and Iran, h. 53.
} 
Syaikh Shaduq adalah ulama abad ke-10 yang dihormati oleh kalangan Syiah karena keahliannya dalam bidang hadits maupun fiqh, ia lahir pada $917 \mathrm{M}$ dan wafat pada 990 M di kota Ray, makamnya menjadi salah satu situs keagamaan yang penting. Di masa pemerintahan Fath Ali pernah terjadi banjir besar yang melanda kota Ray dan berdampak pula pada makam itu. Saat orang-orang menginvestigasinya, ternyata jasad Syaikh Shaduq masih sempurna meski telah wafat hampir 900 tahun. Fath Ali lalu mengutus para ulama dan orang-orang penting guna mengecek apakah ia layak mengunjunginya. Setelah ia memastikan tentang kebenaran isu ini, Fath Ali memerintahkan agar lubangnya ditutup, bangunan makam direkonstruksi dan didekorasi sebaik mungkin menggunakan kaca cermin..$^{34}$

Sebagai seorang Shah, meski tak banyak juga dapat diterima sebagai sesuatu hal yang wajar, kekuasaan Fath Ali telah membuatnya merasa perlu untuk menempuh jalan kekerasan demi keberlangsungan kekuasaan. Belum lagi masalah banyaknya selir yang menghuni harem-nya sedangkan Islam telah membatasi jumlah istri yang bisa dimiliki seorang lelaki Muslim dalam berpoligami. Di tengah kekurangan-kekurangan itu, Fath Ali cenderung menunjukkan perhatiannya dalam masalah-masalah keagamaan. Interaksinya dengan ulama ataupun perhatiannya pada situs-situs suci ialah bagian dari corak kebijakannya dalam memerintah. Dari masa Fath Ali dan setelahnya, Qajar mengikutsertakan kaum ulama serta badanbadan keagamaan, teologi, madrasah-madrasah, ataupun makam-makam suci sebagai salah satu penerima manfaat dari kebijakan istana ; makam-makam suci diperindah dan dibenahi, banyak masjid yang dibangun, para ulama disantuni, sekolah-sekolah teologi didirikan dan dihormati, banyak hadiah yang diberikan pada kaum agamawan maupun makam suci, sebagai tambahan tak jarang para ulama diberikan kewenangan untuk mengampuni pemberontakan dan para penjahat kelas berat, hak tanah wakaf direstorasi serta pembebasan pajak diberlakukan kepada para ulama. ${ }^{35}$ Meskipun ini bisa tergolong sebagai dua sisi mata uang, namun demikianlah kekuasaan yang bersifat absolutisme. Bisa ditemukan dalam sejarah, betapa negara-negara berbasis agama terkadang memiliki pemimpin politik yang "kurang taat" pada ortodoksi. Namun hal itu tidak secara mutlak bisa mendiskreditkan nilai aspirasi keagamaan pemimpin tersebut, yang mana memungkinkan baginya untuk tetap menjadi patron kehidupan beragama di negerinya.

\section{Perang Persia Melawan Rusia}

Di masa Shah Agha Muhammad Khan, sebagaimana dijelaskan sebelumnya, ketegangan melawan Rusia terjadi akibat permasalahan tentang wilayah Georgia. Pasukan Rusia juga sempat menyerang beberapa wilayah Qajar

\footnotetext{
${ }^{34}$ Syaikh Shaduq,, Ali Azhim \& Ali Yahya (Penj.), 'Uyun al-Akhbar al-Ridha as. : Hadits-Hadits Cemerlang Riwayat Imam Ali Ridha Cicit Rasulullah Saw., (Jakarta : Nur Al-Huda, 2014), h. 11.

${ }^{35}$ Birol Baskan, From Religious Empires to Secular States : Secularization in Turkey, Iran, and Russia, (New York : Routledge, 2014), h. 90.
} 
sampai akhirnya konflik lebih jauh setidaknya berhenti akibat ditariknya balatentara Rusia karena Tsarina (Ratu) Catherine mangkat. Dari permasalahan Georgia kita dapat sedikit memahami bahwa soal keagamaan masih banyak berpengaruh dalam ketegangan antara Persia melawan Rusia. Meskipun begitu, persaingan politik internasional pada tujuan akhirnya tentu ialah dominasi teritori ataupun sumber daya. Kita perlu mengerti bagaimana posisi Qajar sebenarnya di tengah pergulatan dinamika internasional yang nantinya juga akan berdampak bagi negeri ini. Sekitar delapan tahun (1804) setelah ketegangan singkat antara Persia di masa Agha Khan dengan Rusia, Fath Ali berusaha untuk mengonsolidasikan kekuasaannya dengan memperkuat otoritas di wilayah tenggara sekitar Laut Kaspia serta selatan Kaukasus. ${ }^{36}$ Pada tahun 1801, Tsar Paul I sebagai pengganti Catherine mangkat dan digantikan oleh Tsar Alexander I yang kemudian mengikat kembali hubungan dagang dan persahabatan dengan Inggris yang sempat putus di masa pemerintahan ayahnya. ${ }^{37}$

Qajar kemudian menemukan dirinya mengalami berbagai tekanan, tepatnya dari tiga arah : Rusia di utara; di timur ada Inggris yang menguasai India serta negeri penyangga baru di Afghanistan; Utsmaniyah Turki di barat (musuh klasik bagi Persia-Pen) serta di Teluk Persia Inggris masih saja menjadi ancaman. Hingga tak heran jika perhatian Qajar Persia untuk masalah internal dan relasi ke luar ialah perlawanan terhadap penetrasi asing. ${ }^{38}$ Fath Ali memerintah pada era kemunculan Napoleon Bonaparte di Prancis yang tengah berkompetisi dengan Inggris; kedua negara itu menyadari bahwa Persia adalah salah satu jalan menuju India. Mereka berusaha mempererat hubungan dengan Qajar Persia melalui pengiriman para duta besar. ${ }^{39}$ Beberapa rombongan kunjungan asing dari dua negara itu antara lain Sir John Malcolm, Sir Hartford Jones, dan Sir Gorozli dari Inggris. Sedangkan Prancis mengirimkan Juber, Romeo, dan Jenderal Gardane. ${ }^{40}$ Dengan begitu setidaknya terdapat tiga kelompok yang memiliki kepentingan dominasi terhadap Persia : Rusia-Inggris yang bersekutu di satu sisi melawan ancaman Napoleon Prancis di pihak lain, serta Utsmaniyah yang masih memungkinkan mempunyai ambisi teritorial. Ancaman yang paling nyata terasa tetaplah Rusia, dengan kembali memakai isu serta perpanjangan tangannya yakni negeri Georgia.

Tsar Alexander I mengagendakan perluasan kekuasaan Rusia hingga melampaui pegunungan Kaukasus. Tahun 1801 Rusia melakukan aneksasi terhadap Kerajaan Kartili-Kakheti di Georgia, Pangeran Paul Tsitsishvili diangkat

${ }^{36}$ Timothy C. Dowling, Russia at War : From the Mongol Conquest to Afghanistan, Chechnya and Beyond , (California : ABC-CLIO.LLC., 2015), h. 728.

${ }^{37}$ Melvin C. Wren, The Course of Russian History, (New York : Macmillan, 1958), h. 327.

${ }^{38}$ Roxane Farmanfarmaian, (Ed.), War and Peace in Qajar Persia : Implications Past and Present, (New York : Routledge, 2008), h. 5.

${ }^{39}$ Zahra Talaei Hatam, dkk., Social and Cultural Images of Qajar-Iran Customs in European Travel Diaries, Jurnal Asian Culture and History, Vol. 7, no. 2, 2015, hal. 29.

${ }^{40}$ Reza Sha'bani, The Book of Iran : Aelection of the History of Iran, (Tehran : Center of International Cultural Studies, 2005), h. 222. 
sebagai panglima perang yang mempercepat ekspansi Rusia terhadap kawasan Kaukasus. Meski merupakan seorang bangsawan asli Georgia, ia dikenang sebagai seorang loyalis yang percaya pada "Misi Pembangunan Peradaban Rusia di Asia." Paul Tsitsishvili bahkan memiliki nama Rusia yang lebih luas dikenal sebagai "Paul (atau 'Pavel') Tsitsianov". Pada rentang tahun 1802-1804 Tsitsianov berusaha memasukkan kawasan barat Kerajaan Imereti, Kepangeranan Mingrelia, Kepangeranan Guria, maupun beberapa kekhanan di seluruh Georgia ke dalam kuasa Rusia. Beberapa di antaranya bersedia bergabung menjadi bawahan Rusia, namun Kekhanan Ganja melakukan perlawanan. Ganja tanpa ampun dijarah oleh Tsitsianov, korban tewas mencapai 3000 orang, dan ribuan lainnya diusir ke Persia. Penyerangan Rusia kepada beberapa kekhanan lainnya yang diakui sebagai vassal dari Persia tak pelak menjadi alasan bagi Fath Ali dalam melancarkan peperangan. Pada tanggal 23 Mei 1804 Persia meminta Russia menarik pasukannya dari selatan Kaukasia, karena terjadi penolakan maka Qajar menyatakan perang. Di musim semi tahun itu pasukan Tsitsianov yang berjumlah antara 3000-5000 orang berbaris menuju Kekhanan Erivan karena penguasanya yang bernama Muhammad Khan menolak tunduk pada Rusia. Lalu gempuran oleh pasukan Rusia dimulai pada bulan Juni, tentara Persia di wilayah itu juga terlibat dalam pertempuran. ${ }^{41}$

Dalam pertempuran ini, ada seorang tokoh Persia yang begitu diingat namanya yakni Na'eb-es-Saltaneh (putra mahkota) Abbas Mirza. Ia adalah pewaris takhta yang telah dipersiapkan oleh Fath Ali Shah. Telah dijelaskan sebelumnya bahwa Abbas dipilih oleh sang ayah untuk menjadi Beylerbeyi atau "GubernurJenderal" di Azerbaijan sejak 1799, atau kira-kira saat usianya masih 10 tahun. Di usia yang masih muda, Abbas Mirza harus menghadapi serangan bangsa asing. Ujian yang berat itu segera dihadapi oleh Abbas Mirza. Dengan terampil ia memimpin sendiri pasukannya menghadang pasukan Rusia di Echmiadzin dan bertempur selama tiga hari. Taktik yang dipakai Abbas Mirza ialah dengan melakukan pengepungan lingkar terhadap pasukan Rusia dan mencegah mereka memperoleh pasokan perang. Taktik itu bahkan lebih jauh menghancurkan belenggu pengepungan Rusia untuk merebut Erivan. Pasukan Tsitsianov menanggung kerugian 4000 korban jiwa dan dipaksa mundur. ${ }^{42}$

Kemenangan Qajar pada bulan Juli 1804 itu menyebabkan Tsitsianov merasa terancam dalam karirnya, ia melapor kepada Tsar Alexander I bahwa penyebab kekalahannya adalah kegagalan Jenderal Pangeran Dmitri Petrovich Volkonsky dalam membawa pasokan perang. Kemenangan Persia juga tidak semudah yang dibayangkan. Pada peperangan itu di pihak Rusia dikenal nama Peter Koltyarovsky, seorang anak pendeta Ortodoks Rusia yang mengabdi sebagai perwira di jajaran tentara Tsitsianov. Koltyarovsky menjadi terkenal - bahkan sebagai idola publik Rusia - saat ia dan 600 prajurit Infanteri Ringan ke-17 serta

${ }^{41}$ Timothy C. Dowling, Russia at War : From the Mongol Conquest to Afghanistan, Chechnya and Beyond , 728

${ }^{42}$ Michael Clodfelter, Warfare and Armed Conflicts : A Statistical Encyclopedia of Casual and Other Figures, 1492-2015 , (North Carolina: McFarland \& Company, Inc., 2017), h. 213. 
dua meriam berusaha menghadang laju prajurit Abbas Mirza yang membawa ribuan orang. Meskipun ia harus kehilangan $1 / 3$ prajuritnya, Koltyarovsky mampu menahan Persia selama dua hari, termasuk mempertahankan benteng Shah-Bulah sebelum nantinya diselamatkan oleh Tsitsianov. Tiga luka harus diterima selama peperangan oleh Koltyarovsky. Untuk keberaniannya itu, ia dianugerahi dengan medali Order of St. Vladimir $4^{\text {th }}$ Class. Di bulan Agustus 1804, Koltyarovsky kembali beraksi dengan gemilang sewaktu menekan perlawanan orang-orang Karabakh dan juga menyerang kota Baku. ${ }^{43}$

Dentuman meriam kedua belah pihak kembali meletus satu tahun berikutnya. Di tahun 1805, Karabakh, Shakki, dan Shirvan mengakui kekuasaan Rusia. Pasukan Rusia melanjutkan serbuan ke Baku dan Resht. Walaupun Tsitsianov dibunuh pada Februari 1806 di sekitar Baku, Rusia kembali sukses memukul mundur serbuan Persia ke Karabakh pada musim panas, berikut dengan menduduki Derbent. ${ }^{44}$ Di bulan Juni 1806, Koltyarovsky mengomandani pasukan dalam Perang Khonashin, saat 1.644 pasukan Rusia mengalahkan sekitar 20.000 tentara Qajar yang dipanglimai oleh Pangeran Abbas Mirza sendiri : Koltyarovsky diganjar kenaikan pangkat sebagai kolonel karena kemenangan ini. Perang tanpa munculnya pemenang terus berlangsung sampai tahun 1812 saat Rusia disibukkan dengan peristiwa yang terjadi di daratan Eropa (Perang Napoleon). Sejumlah peristiwa bergulir dalam rentang waktu 1805-1812 yang bagi Persia sangatlah penting.

Fath Ali Shah yang juga mengikuti perkembangan di Eropa menuliskan surat pada Napoleon bahwa ia kagum atas kemenangan-kemenangan Prancis. Ini adalah salah satu cara bagi Qajar untuk memperoleh dukungan dunia Barat. Sebuah perjanjian persekutuan yang dikenal dengan Traktat Finkenstein lalu ditandatangani oleh kedua negara, isinya adalah Prancis mengakui Georgia sebagai wilayah yang sah milik Iran serta kesiapan negeri itu untuk membantu Shah merebutnya kembali dari tangan Rusia. ${ }^{45}$ Misi Prancis pertama kali sampai ke Iran di bawah pimpinan Jenderal Gardane yang tiba di Tehran pada tahun 1807. Traktat Finkenstein menjadi penanda bahwa Iran bergabung dengan Prancis melawan Inggris dan Rusia. Dua perwira yakni Kapten Fabvier dan Reboul dikirim ke Isfahan guna mendirikan pabrik meriam, sedangkan dua lainnya yaitu Kapten Verdier dan Lamy, bersama tiga penerjemah serta bintara, pergi menuju kota kedudukan Abbas Mirza di Tabriz menjadi instruktur militer. Perwira-perwira Prancis lainnya mulai berkeliling negeri Persia untuk mengumpulkan informasi

${ }^{43}$ Alexander Mikaberidze (Ed.), Conflict and Conquest in the Islamic World : A Historical Encyclopedia, h. 203.

${ }^{44}$ Timothy C. Dowling, Russia at War : From the Mongol Conquest to Afghanistan, Chechnya and Beyond, 729.

${ }^{45}$ Hooshang Amirahmadi, The Political Economy of Iran Under the Qajars, (London : I.B. Tauris \& Co. Ltd., 2012), h. 144. 
intelijen sembari melakukan survey tentang distrik dan rute yang bisa dipakai Prancis menyerang India. ${ }^{46}$

Kapten Verdier mulai membentuk dan melatih tiga resimen infanteri, antara 4000 sampai 6000 orang. Prajurit-prajurit yang kemudian dinamai Sarbaz, dipersenjatai dengan senapan musket buatan Tabriz dengan gaya Prancis, mereka turut diberi seragam nasional bergaya Prancis tapi dengan topi kulit domba hitam ala Persia. Kapten Lamy bertugas mengarahkan pembangunan barak, arsenal, pabrik mesiu, meriam, perbentengan, serta ikut mendirikan sekolah politeknik guna melatih "perwira-insinyur" yang mana sang putra mahkota, Abbas Mirza, ikut menjadi salah satu siswanya. Pekerjaan telah dimulai dalam mengorganisir pasukan artileri yang dipimpin oleh Tahmuras Khan, bangsawan Kristiani dari keluarga pangeran terakhir Georgia. ${ }^{47}$ Hanya sekitar dua bulan setelah Traktat Finkenstein (Juli 1807), bagaimanapun Napoleon mengikat perdamaian dengan Rusia di Tilsit dan pengaruh Prancis di Persia mulai runtuh. Pejabat luar negeri Inggris mulai mengambilalih kendali masalah Persia yang sebelumnya di bawah kongsi dagang East India Company (EIC) dan mengirim duta besar yakni Sir Hartford Jones, untuk menjelek-jelekkan Prancis di Tehran. Jones ikut menawarkan Qajar bantuan dana maupun asistensi kemiliteran melawan Rusia yang disetujui dengan penandatanganan perjanjian tahun $1809 .{ }^{48}$

Pada tahun 1812 Abbas Mirza telah memiliki sebuah tentara bergaya Eropa - disebut sebagai Nezam-e Jadid (Prajurit Baru) - sekitar 13.000 orang yang terdiri dari infanteri, kavaleri, dan artileri. Abbas beserta ayahnya percaya bahwa kemenangan melawan Rusia akan segera digapai. Dalam pasukan Nezam Qajar ada seorang desertir Rusia yang dikenang dalam kemiliteran Persia bernama Samson Yakovlevich Makintsev atau "Samson Khan." Samson Khan adalah seorang mantan bintara di kesatuan kavaleri Nizhni-Novgorod, namun ia melakukan desersi serta menjadi perwira di jajaran angkatan bersenjata Qajar. Samson Khan berperan dalam mempengaruhi segelintir orang Rusia untuk desersi dan membelot ke Persia. Walaupun resimen yang baru tumbuh itu hanya memperoleh beberapa kemenangan kecil di tahun 1810, Abbas Mirza berharap dapat memanfaatkan kelemahan Rusia selama diinvasi oleh Napoleon di tahun 1812, sayangnya ia harus kecewa dan perang akhirnya berakhir setelah resimen Nezam itu menderita serangkaian kekalahan. Empat perwira Inggris dan 12 bintaranya telah mendampingi prajurit Persia dalam peperangan, walau para pasukan Persia itu sempat mencuri satu kemenangan ketika mereka dikirim melawan militer Rusia di Sultanabad dekat Sungai Aras pada bulan Februari 1812, kampanye militer Persia berakhir dengan kekalahan telak dalam Perang Aslanduz di bulan Oktober.

\footnotetext{
${ }^{46}$ Roxane Farmanfarmaian (Ed.), War and Peace in Qajar Persia : Implications Past and Present, h. 55 .

${ }^{47}$ Roxane Farmanfarmaian (Ed.), War and Peace in Qajar Persia : Implications Past and Present, h. 56 .

${ }^{48}$ Elton L. Daniel, The History of Iran, (Westport : Greenwood Press, 2001), h. 103.
} 
Seorang perwira Inggris bernama Charles Christie ikut gugur di dalamnya. ${ }^{49}$ Padahal sebelumnya Abbas Mirza sempat menyerbu selatan Azerbaijan yakni wilayah kekhanan Talysh serta merebut benteng Lenkoran. Di bulan Oktober pula pasukan Persia kembali mencapai sungai Aras serta menyerang detasemen kecil Rusia yang berjumlah 2000 orang pimpinan Koltyarovsky yang kini telah berpangkat Jenderal. Tak disangka pasukan Qajar kalah. Pada 13 Januari 1813, pasukan Rusia menggempur Lenkoran dan memaksa Persia untuk ke meja perundingan. ${ }^{50}$

Perang antara Persia dan Rusia untuk sementara berhenti. Negosiasi yang digelar dengan Inggris sebagai mediatornya kemudian membuahkan hasil berupa penandatanganan traktat di Gulistan pada 14 Oktober 1813. Traktat Gulistan memaksa Fath Ali Shah melepas klaimnya di wilayah selatan Kaukasus. Persia kehilangan seluruh teritori kekuasaannya di utara sungai Aras, termasuk Daghestan, semua kawasan Georgia, dan bagian-bagian Armenia serta Azerbaijan. Shah Iran juga mesti melepaskan hak pelayarannya di Laut Kaspia dan memberi "hak eksklusif" bagi Rusia dalam mendirikan armada militer di sana, ditambah lagi hak-hak perdagangan bersama Iran. Sebaliknya, Rusia berjanji mendukung putra mahkota Abbas Mirza sebagai pewaris takhta Qajar Persia. ${ }^{51}$

Pada tahap awal pasca Traktat Gulistan, Fath Ali Shah masih mengusahakan jalur diplomasi terhadap Rusia. Fath Ali kemudian mengirim mantan duta besar Persia untuk Inggris, Abu Hasan Khan Shirazi, ke St. Petersburg (Rusia) guna bertemu Count (Pangeran) Karl von Neselrode selaku menteri luar negeri. Shirazi meminta kejelasan perbatasan wilayah konsesi selain menaikkan isu bahwa tentara Rusia kerap melanggar perbatasan dengan Qajar. Neselrode tiada mengusahakan akomodasi apapun pada permintaan Shirazi namun Rusia berusaha memberikan sedikit bagian kepada Persia sebagai konsesi balik. Jenderal Alexei Petrovich Yermolov (veteran dan pahlawan Perang Borodino 1812), pejabat panglima perang baru Rusia di Kaukasia dikirim sebagai duta besar pada tahun 1817 untuk berkompromi dengan Persia. Di Kaukasus Yermolov mendapat julukan "Gengiz Khan" karena kekejamannya. Sesampainya di Tehran jelas Yermolov yang tak bisa bertindak fleksibel itu malah memperbesar api permusuhan dengan Tehran. Ia bahkan tak menghormati tuan rumah, termasuk Fath Ali Shah sebagai penguasa. ${ }^{52}$ Yermolov dikenal dengan pribadi yang serupa dengan pendahulunya, Tsitianov, dalam memandang orang-orang "Asiatik" sehingga kata "perang" diartikan sebagai tujuan politik Rusia. Panglima Yermolov mengambil langkah

57.

${ }^{49}$ Roxane Farmanfarmaian (Ed.), War and Peace in Qajar Persia : Implications Past and Present,

${ }^{50}$ Timothy C. Dowling, Russia at War : From the Mongol Conquest to Afghanistan, Chechnya and Beyond , 729.

${ }^{51}$ Timothy C. Dowling, Russia at War : From the Mongol Conquest to Afghanistan, Chechnya and Beyond , 729.

${ }^{52}$ Kaveh Farrokh, Iran At War: 1500-1988 , (Oxford : Osprey Publishing, 2011), h. 195. 
berikutnya dengan menduduki Mirak di Kekhanan Erivan, tindakan itu menandai pelanggaran pada Traktat Gulistan. ${ }^{53}$

Tindakan Rusia menyebabkan para elite militer serta kaum ulama memaksa Shah untuk membatalkan isi Traktat Gulistan, pasukan Persia di bawah Abbas Mirza segera menyeberangi sungai Aras menuju posisi Rusia pada 16 Juli $1826 .{ }^{54}$ Apalagi Rusia juga menindas kaum Muslim di sana sehingga rakyat Persia amat berang. Respon balasan Persia ditunjukkan dengan penyerbuan pada Kekhanan Karabagh dan Talysh, para penguasa lokal segera mengubah ketertundukan dan menyerahkan beberapa kota seperti Lenkoran, Kuba, dan Baku pada Persia. Walau Abbas Mirza sukses merebut kembali wilayah yang sedemikian besar pada bulanbulan awal peperangan, gerakan ofensifnya harus terhambat. Garnisun Rusia di Shusha dengan heroik mempertahankan benteng mereka selama 48 hari, perkembangan itu memberikan keleluasaan untuk Yermolov menggerakkan kekuatan cadangan menuju medan laga. Serangan balik Rusia segera menghantam kekuatan Persia, mereka memukul pasukan Muhammad Mirza yang tak lain ialah putra Abbas Mirza di sungai Shamkhor di tanggal 15 September dan menundukkan Abbas Mirza di Ganja pada tanggal 26 September. Kekalahankekalahan ini mengubah angin peperangan sehingga Rusia di bawah Jenderal Pashkevich merangsek ke Erivan dengan terus mendesak sang putra mahkota Qajar. Kota-kota seperti Nakhichevan, Abbasabad, Meren, Urmiya, Ardabil, bahkan Tabriz direbut Rusia. ${ }^{55}$ Abbas Mirza amat tidak beruntung. Setelah itu banyak tentara relawannya dibubarkan karena Fath Ali yang kikir itu tak mau membayar atau membiayai mereka di musim dingin, pada saat kegiatan perang berhenti. Maka Rusia dapat memaksa Persia mengikat perjanjian dalam Traktat Turkomanchai (1828) ..$^{56}$

Jika kita membaca buku berjudul Iran Tanah Peradaban yang diterbitkan oleh Kedutaan Besar Republik Islam Iran, dalam penjelasan singkat tentang Dinasti Qajar dikatakan "...Di bawah penguasa suksesinya (Agha Muhammad-Pen)-Fath Ali Shah, Muhammad Shah dan Nashiruddin Shah- tercipta suatu kondisi relatif aman di negeri Iran. Namun sejak awal abad ke-19, Dinasti Qajar mulai menghadapi tekanantekanan dari dua kekuatan besar dunia saat itu, Rusia dan Inggris..." 57 Berlakunya hukum "relatif" yang dimaksud kemungkinan karena Fath Ali Shah tidak begitu direpotkan oleh urusan internal, hampir semua ancaman dan pergolakan berasal

${ }^{53}$ Timothy C. Dowling, Russia at War : From the Mongol Conquest to Afghanistan, Chechnya and Beyond , 729.

${ }^{54}$ Erik Goldstein, Wars and Peace Treaties 1816-1991, (London : Routledge, 1992), h. 72.

${ }^{55}$ Timothy C. Dowling, Russia at War : From the Mongol Conquest to Afghanistan, Chechnya and Beyond, 730 .

${ }^{56}$ Muhammad Hasyim Assagaf, Lintasan Sejarah Iran : Dari Dinasti Achaemenia ke Republik Islam Iran, h. 396.

${ }^{57}$ ICRO, Iran Tanah Peradaban, (Jakarta : Kedutaan Besar Republik Islam Iran, 2009), h. 23. 
dari luar, yang faktanya lebih banyak dihadapi oleh putra mahkotanya - Abbas Mirza. Dampak perjanjian Turkomanchai cukup signifikan bagi kekuasaan Persia karena mereka tidak lagi bisa mengklaim wilayah-wilayah kekuasaan di Armenia timur dan Kaukasus, tetapi gerakan maju Rusia di Asia Tengah menimbulkan bahaya potensial lebih lanjut bagi tapal batas timur-laut Persia. ${ }^{58}$

Fath Ali Shah yang telah memerintah selama kurang lebih 35 tahun, mestinya tidak bisa menafikan peran besar sang putra mahkotanya - Abbas Mirza. Selaku calon pengganti sang ayah, Abbas Mirza sudah begitu banyak berjuang dalam membela bangsanya. Kesehatannya yang kian menurun telah membuat Abbas kehilangan gairah dalam memperjuangkan reformasi kemiliteran, apalagi ia sadar bahwa sang ayah justru kerap menjadi penghalang dari gagasannya itu. Abbas Mirza akhirnya wafat pada 25 Oktober 1833 tatkala memimpin pasukan ke wilayah timur. Kabar yang beredar mencurigai Fath Ali telah meracuni putranya untuk meredam celaan publik akibat kritik terbuka Abbas atas penarikan dukungan sang Shah bagi pasukan Persia. ${ }^{59}$ Entah benar atau tidak isu tersebut, hingga kini belum dapat dipastikan. Karena kematian itu pada bulan Safar 1250 H/Juni 1834, sekitar empat bulan sebelum ajal yang nanti turut menjemput sang Shah, Fath Ali menunjuk putra mendiang Abbas Mirza yakni Muhammad Mirza sebagai penggantinya. ${ }^{60}$ Fath Ali Shah menghembuskan nafas terakhirnya pada tanggal 23 Oktober 1834, sejak itu cucunya tak lagi memakai nama "Muhammad Mirza", ia berangkat dari wilayah Azerbaijan untuk mengukuhkan gelarnya sebagai "Muhammad Shah Qajar".

\section{Kesimpulan}

Berdasarkan ulasan di atas, dalam rentang waktu sejak pendirian Dinasti Qajar pada tahun 1796 yang ditandai dengan diangkatnya Agha Muhammad Khan sebagai Shah Persia hingga pada tahun 1834 yakni kematian pengganti Agha Muhammad, Fath Ali Shah, telah dapat disimpulkan beberapa aspek penting dalam kondisi politik di masa awal otoritas politik tersebut :

Pertama, terjadinya kekerasan-kekerasan seputar persaingan politik di dalam negeri Persia berupa penyiksaan fisik seperti pengebirian maupun pembutaan dan bahkan pembunuhan. Sejak sebelum Qajar berdiri, Persia telah menjadi tempat persaingan antar beberapa kekuatan politik yang ingin menguasai seluruh kawasan ini. Agha Muhammad selaku putra dari ketua suku Qajar termasuk yang mendapat dampak langsung dari kekerasan itu. Sebaliknya, Agha Muhammad turut melakukan kekerasan-kekerasan kepada musuh-musuhnya. Fath Ali Shah yang menggantikan Agha Muhammad turut melakukan tindakan-tindakan kejam dalam mempertahankan kekuasaannya. Beberapa saingan untuk merebut takhta Qajar, entah yang berasal dari lingkaran keluarga / saudara, maupun mereka yang di luar

${ }^{58}$ C.E. Bosworth, Dinasti-Dinasti Islam, h. 203-204.

${ }^{59}$ D.L. Bradley, Dictionary of Iran : A Shorter Encyclopedia, h. 7.

${ }^{60}$ Kambiz Eslami, Iran and Iranian Studies : Essays in Honor of Iraj Afshar, (New Jersey : Zagros Press, 1998), h. 220 
itu (contohnya adalah Haji Ibrahim Kalantar), ikut menjadi korban dari tindakan Fath Ali. Apabila isu kematian Abbas Mirza yang meninggal akibat diracun oleh Fath Ali kelak dapat dibuktikan secara historis, hal ini menandai bahwa Shah kedua dinasti ini pun tak segan untuk menyingkirkan putranya sendiri apabila dinilai membahayakan kekuasaannya.

Kedua, konsolidasi kekuatan politik di dalam negeri Persia yang cukup baik. Hal ini masih berkaitan dengan kekerasan-kekerasan yang disebutkan sebelumnya. Agha Muhammad telah menjadi contoh nyata betapa Qajar didirikan melalui serangkaian pertempuran guna menundukkan pesaing-pesaingnya di dalam lingkup negeri Persia. Mungkin sebagai pengecualian ialah peristiwa pembunuhan Agha Muhammad yang lebih disebabkan kelalaiannya sendiri. Namun untuk masa selanjutnya, Agha Muhammad berhasil memastikan integritas anta-klan suku Qajar (Qavanlu dan Develu-Yukharibash) serta mengamankan suksesi takhtanya dengan menunjuk Fath Ali. Dapat dikatakan, manajemen pemerintahan sipil Qajar yang sesungguhnya baru dimulai pada masa Fath Ali. Orang-orang Mazandaran maupun sisa-sisa birokrat Zand tetap diikutsertakan dalam tata kelola pemerintahan era Fath Ali, yang mana ia juga tidak melalaikan aspek kehidupan beragama rakyatnya.

Ketiga, lemahnya kemiliteran yang berdampak pada aneksasi bangsa asing. Walaupun Agha Muhammad sempat beberapa kali menghalau Rusia - iapun terbunuh saat melancarkan kampanye melawan Rusia - dari Persia, namun negeri ini menanggung kehilangan teritori yang cukup luas selama pemerintahan dua Shah Qajar. Faktor utama yang menyebabkannya adalah ketertinggalan teknologi maupun taktik kemiliteran. Dalam struktur tertinggi pemerintahan pusat memang terdapat jabatan menteri Lashkar Nevis (Peperangan), namun kementerian ini terpisah dari bagian lainnya yakni Shahib Divan (Penggajian), sehingga jajaran militer tidak mendapatkan pembayaran gaji yang rutin atau bisa disebut lebih menyerupai milisi sukarelawan. Permasalahan itu yang masih ditambah lagi dengan keengganan dukungan penuh Fath Ali, semakin mempersulit usaha Na'eb-esSaltaneh Abbas Mirza untuk memperkuat pasukan modern pertama Persia, Nezam-e Jadid. Fath Ali lebih mempercayai bantuan-bantuan pihak asing dari Prancis maupun Inggris yang sejatinya adalah bentuk intervensi terhadap Persia. Karena bantuan yang diterima sifatnya terbatas, Persia tidak memperoleh manfaat besar untuk dapat mereformasi kemiliterannya. Akhirnya negeri ini tidak dapat membendung ambisi aneksasi yang dilancarkan oleh Kekaisaran Rusia.

\section{DAFTAR PUSTAKA}

Abbas Amanat, Pivot of the Universe : Nasir al-Din Shah Qajar and the Iranian Monarchy 1851-1896, London : I.B. Tauris, 1997.

Alexander Mikaberidze (Ed.), Conflict and Conquest in the Islamic World: A Historical Encyclopedia, California : ABC-CLIO,2011.

Ann. K.S. Lambton, Bernard Lewis (Ed.), The Cambridge History of Islam, London : Cambridge University Press, 1970. 
Ardison Muhammad, Iran : Sejarah Persia Ė Lompatan Masa Depan Negeri Kaum Mullah, Surabaya : Liris, 2010.

Badri Yatim, Sejarah Peradaban Islam Dirasah Islamiyah II, Jakarta : PT. RajaGrafindo Persada, 2008.

Birol Baskan, From Religious Empires to Secular States : Secularization in Turkey, Iran, and Russia, New York : Routledge, 2014.

C.E. Bosworth, Dinasti-Dinasti Islam, Bandung : Mizan, 1993.

D.L. Bradley, Dictionary of Iran : A Shorter Encyclopedia, North Carolina : lulu.com Publisher, 2016.

Daniel T. Potts, Nomadism In Iran : From Antiquity to the Modern Era, New York : Oxford University Press 2014.

Elton L. Daniel, The History of Iran (2nd Edition), California : Greenwood, 2012. , The History of Iran, Westport : Greenwood Press, 2001.

Erik Goldstein, Wars and Peace Treaties 1816-1991, London : Routledge, 1992.

Zackery M. Heern, The Emergence of Modern Shiism : Islamic Reform in Iraq and Iran, London : Oneworld, 2015.

Hooshang Amirahmadi, The Political Economy of Iran Under the Qajars, London : I.B. Tauris \& Co. Ltd., 2012.

Hormoz Ebrahimnejad, Medicine, Public Health, and the Qajar State, Leiden : Brill, 2004.

ICRO, Iran Tanah Peradaban, Jakarta : Kedutaan Besar Republik Islam Iran, 2009.

Jeremy Black, War in the Eighteenth-Century World, Hampshire : MacMillan Palgrave, 2012.

John H. Lorentz, The A to Z of Iran, Maryland : Scarecrow, 2010.

John Middleton, World Monarchies and Dynasties, New York : Routledge, 2015.

Kambiz Eslami, Iran and Iranian Studies : Essays in Honor of Iraj Afshar, New Jersey: Zagros Press, 1998.

Kaveh Farrokh, Iran At War : 1500-1988, Oxford : Osprey Publishing, 2011.

Melvin C. Wren, The Course of Russian History, New York : Macmillan, 1958.

Michael Clodfelter, Warfare and Armed Conflicts : A Statistical Encyclopedia of Casual and Other Figures, 1492-2015 , North Carolina: McFarland \& Company, Inc., 2017.

Muhammad Hasyim Assagaf, Lintasan Sejarah Iran : Dari Dinasti Achaemenia ke Republik Islam Iran, Jakarta : The Cultural Section of Embassy of The Islamic Republic of Iran, 2009.

Pat Yale, dkk., Iran, Victoria : Lonely Planet Publication, 2001.

Patricia L. Baker, Hillary A. Smith, Iran, Buckinghamshire : Bradt Travel Guide, 2014.

Reza Sha'bani, The Book of Iran : Aelection of the History of Iran, Tehran : Center of International Cultural Studies, 2005.

Robert Gleave (Ed.), Religion and Society in Qajar Iran, New York : RoutledgeCurzon, 2005. 
Saeed Shirazi, A Concise History of Iran : From the Early Period to the Present Time, Los Angeles USA : Ketab Corporation, 2018.

Syaikh Shaduq, Ali Azhim \& Ali Yahya (Penj.), 'Uyun al-Akhbar al-Ridha as. : HaditsHadits Cemerlang Riwayat Imam Ali Ridha Cicit Rasulullah Saw., Jakarta : Nur Al-Huda, 2014.

Timothy C. Dowling, Russia at War: From the Mongol Conquest to Afghanistan, Chechnya and Beyond, California : ABC-CLIO.LLC., 2015.

William Bayne Fisher, P. Avery, The Cambridge History of Iran, Volume 7, New York : Cambridge University Press, 1968.

Zahra Talaei Hatam (et.al), Social and Cultural Images of Qajar-Iran Customs in European Travel Diaries, Jurnal Asian Culture and History, Vol. 7, no. 2, 2015. 